\title{
Marie-Olympe de Gouges, une humaniste à la fin du XVIIIe siècle
}

Jean-Clément Martin

\section{(2) OpenEdition \\ 12 Journals}

Édition électronique

URL : https://journals.openedition.org/ahrf/1560

DOI : 10.4000/ahrf.1560

ISSN : 1952-403X

Éditeur :

Armand Colin, Société des études robespierristes

\section{Édition imprimée}

Date de publication : 1 septembre 2004

Pagination : 216

ISSN : 0003-4436

\section{Référence électronique}

Jean-Clément Martin, « Marie-Olympe de Gouges, une humaniste à la fin du XVIIle siècle », Annales historiques de la Révolution française [En ligne], 337 | juillet-septembre 2004, mis en ligne le 15 février 2006, consulté le 22 avril 2022. URL : http://journals.openedition.org/ahrf/1560 ; DOI : https://doi.org/ 10.4000/ahrf.1560

Ce document a été généré automatiquement le 22 avril 2022.

Tous droits réservés 


\title{
Marie-Olympe de Gouges, une humaniste à la fin du XVIIIe siècle
}

\author{
Jean-Clément Martin
}

\section{RÉFÉRENCE}

Olivier Blanc, Marie-Olympe de Gouges, une humaniste à la fin du XVIIIe siècle, Éditions René Viénet, 2003, ISBN 2849830003.

Olivier Blanc est bien connu pour ses ouvrages sur la période révolutionnaire, il avait déjà publié une biographie consacrée à 0 . de Gouges qui est ici rééditée au terme d'une relecture des sources et de l'historiographie récente. Le récit qui est donné de cette vie tranchée en 1793 est celle d'une femme, sans doute fille naturelle de Lefranc de Pompignan, venu à Paris vivre dans le monde des littérateurs et des salons, bénéficiant de l'appui d'un amant riche, qui entre peu à peu dans la vie publique et politique, s'affirme dans le camp des Girondins et est guillotinée pour avoir défendue une ligne politique humaniste, contre l'esclavage et la violence populaire, contre les récupérations de la Montagne, pour la révision de la place des femmes. L'auteur lave 0. de Gouges des accusations ordinaires de libertinage sans limite, comme de ses échecs littéraires, il est convaincant dans sa présentation d'un itinéraire qui ne peut que se situer hors des chemins battus, puisqu'elle est réformatrice sans accepter les ruptures révolutionnaires, qu'elle se propose pour défendre le roi et qu'elle se fait le chantre d'un féminisme "politique » modéré. Dans le débat actuel, le livre s'inscrit contre la lecture de Joan Scott, sans doute très marqué par le vocabulaire psychanalytique, en se situant dans une histoire narrative et érudite ; mais ce faisant, il ne répond cependant pas à l'énigme posée par cette vie conduite dans l'invention de situations ambiguës, entre des milieux différents, qui additionne des postures sociales plus qu'elle ne prend des partis précis. Est-ce lié à une personnalité particulière, ou est-ce représentatif de la place accordée aux femmes dans la société du XVIIIe siècle au moment de la Révolution? Les textes proprement politiques demeurent peu étudiés dans cet ouvrage qui privilégie la description du cadre de la vie et des relations personnelles - qu'il est 
certes dangereux de négliger - et qui contribue ainsi à une réhabilitation d'un auteur malheureux, d'une politique souvent mal comprise. Quelques coquilles auraient pu être évitées, Wimpffen, Wollstonecraft, cette dernière devenant mère de Shelley. 